\title{
MOTIVASI GURU DAN PRESTASI BELAJAR PESERTA DIDIK
}

\author{
YASID ASSYAUQI, SUARGA \\ Fakultas Tarbiyah dan Keguruan UIN Alauddin Makassar \\ Jl. HM. Yasin Limpo No. 36 Makassar \\ Email: yasidnickdidaz@gmail.com, suargabk@gmail.com
}

\begin{abstract}
:
This type of research is to study the description of teacher motivation in SMA Negeri 1 Mamasa Kab. Mamasa Prov, Sul-Bar; To find out how to learn student achievement in SMA Negeri 1 Mamasa Kab. Mamasa Prov, Sul-Bar; To find out the motivation to learn teachers about student learning achievement in SMA Negeri 1 Mamasa Kab. Mamasa Prov, Sul-Bar. The population of the study consisted of all teachers in the field of 40 succession studies in SMA Negeri 1 Mamasa Kab. Mamasa Prov, Sul-Bar. The entire population was used as the total sampling in this study. Data were analyzed using simple regression. Research Results encourage (1) An overview of teacher motivation in SMA Negeri 1 Mamasa Kab. Mamasa Prov, Sul-bar shows that the teacher motivation index scores obtained were $87.46 \%$ or included in the category of excellent teacher motivation (2) An overview of students' learning achievements in SMA Negeri 1 Mamasa, Kab. Mamasa Prov, Sul-bar shows that the value of students' learning achievement of $88.63 \%$ is included in the category of good student learning achievement (3) Motivation of teachers against student achievement in SMA Negeri 1 Mamasa, Kab. Mamasa Prov, Sul-Bar, this is evidenced by the significance value of 0.08 smaller when compared to $\alpha$ at the 0.05 significance level. The implications of research research that contains suggestions in this study are based on research findings that produce a $R$ Square value of 0,17 shows the ability of the independent variable in explaining the devendent variable of $17.0 \%$ is accepted at $83.0 \%$ requested by other variables not discussed in this study. This means that the teacher's motivation variable has little effect on students' learning achievement. Based on this, it is suggested in this study: (1) To the school that suggests doing a business that can increase teacher motivation, this motivation can be in the form of giving awards or awards to outstanding teachers; (2) To further research to add other variable variables that have not been revealed in this study.
\end{abstract}

Keywords: Motivation to Teach Teachers, Student Learning Achievement

\section{PENDAHULUAN}

endidikan dan pengajaran adalah suatu proses yang sadar tujuan. Tujuan dapat diartikan sebagai suatu usaha untuk memberikan rumusan hasil yang diharapkan siswa setelah melaksanakan pengalaman belajar. Tercapai tidaknya tujuan pengajaran salah satunya adalah terlihat dari prestasi belajar yang diraih siswa. Dengan prestasi yang tinggi, para siswa mempunyai indikasi berpengetahuan yang baik (Sardiman, 2004:56).

Salah satu faktor yang mempengaruhi prestasi adalah motivasi. Dengan adanya motivasi, siswa akan belajar lebih keras, ulet, tekun dan memili konsentrasi penuh dalam proses belajar. Dorongan motivasi dalam belajar merupakan salah satu hal yang perlu dibangkitkan dalam upaya pembelajaran disekolah.

Penelitian Wasty Soemanto menyebutkan, pengenalan seseorang terhadap prestasi belajarnya adalah penting, karena dengan mengetahui hasil-hasil yang 
sudah dicapai maka siswa akan lebih berusaha meningkatkan prestasi belajarnya. Dengan demikian peningkatan prestasi belajar dapat lebih optimal karena siswa tersebut merasa termotivasi untuk meningkatkan prestasi belajar yang telah diraih sebelumnya. (Westy, 2003)

Sekolah Menengah Atas (SMA) sebagai salah satu pendidikan terakhir sebelum melanjutkan ke jenjang pendidikan yang lebih tinggi diuniversitas, dapat memberikan peranan dan pengalaman bagi siswa untuk mengasah skil dan pengetahuan. Hasil pembelajaran di SMA sangat dipengaruhi oleh motivasi dari peserta didik, baik itu motivasi internal maupun motivasi eksternal. Pembelajaran di SMA dilakukan dengan berbagai upaya, yaitu salah satunya melalui peningkatan motivasi belajar. Dalam hal belajar siswa akan berhasil jika dalam dirinya sendiri ada kemauan untuk belajar dan keinginan atau dorongan untuk belajar, karena dengan peningkatan motivasi belajar maka siswa akan tergerak, terarahkan sikap dan perilaku siswa dalam belajar, dalam hal ini belajar di Sekolah Menengah Atas (SMA).

Slameto mengemukakan bahwa belajar adalah serangkaian kegiatan jiwa raga untuk memperoleh suatu perubahan tingkah laku sebagai hasil dari pengalaman individu dalam interaksi dengan lingkungannya menyangkut kognitif, afektif, dan psikomotorik. Dalam belajar, siswa mengalami sendiri proses dari tidak tahu menjadi tahu. (Slameto, 2003)

Menurut Purwanto (2004:102) Faktor-faktor yang mempengaruhi belajar dapat dibedakan menjadi dua golongan yaitu faktor yang berasal dari diri individu disebut faktor internal dan faktor yang ada di luar individu yang disebut faktor eksternal. Faktor internal terdiri dari faktor kecerdasan, bakat, minat dan perhatian, motif dan cara belajar sedangkan faktor eksternal terdiri dari faktor lingkungan keluarga dan lingkungan sekolah. Jadi, keberhasilan siswa mencapai hasil belajar yang baik dipengaruhi oleh berbagai macam faktor, faktor itu terdiri dari tingkat kecerdasan yang baik, pelajaran sesuai bakat yang dimiliki, ada minat dan perhatian yang tinggi dalam pembelajaran, motivasi yang baik dalam belajar, cara belajar yang baik dan strategi pembelajaran variatif yang dikembangkan guru. Suasana keluarga yang memberi dorongan anak untuk maju. Selain itu, lingkungan sekolah yang tertib, teratur, disiplin, yang kondusif bagi kegiatan kompetisi siswa dalam pembelajaran.

Di sisi lain, motivasi untuk selalu mengembangkan diri dengan tujuan meningkatkan kompetensi yang dimiliki oleh guru mutlak diperlukan agar mampu bersaing dan mengikuti perkembangan. Bersedia mencari, menganalisis, berfikir lebih, dan bekerja keras merupakan kunci untuk menjadi guru yang ideal, meskipun tantangan untuk menjadi seorang guru profesional sebagai fasilitator dalam memberikan arahan dan motivasi terhadap peserta didik tidaklah mudah jika masih belum memahami kesesuaian peserta didik dalam mempengaruhi belajar peserta didik yang lebih aktif. Itu semua demi terwujudnya proses pendidikan yang baik sehingga mampu menghasilkan peserta didik yang berkualitas pula. Peserta didik yang dikatakan sebagai output/produk dari sebuah lembaga pendidikan, baik 
buruknya akan ditunjukkan pada prestasi belajarnya, sehingga proses penginputan perilaku peserta didik dari lembaga pendidikan itu sendiri (guru, lingkungan sekolah dan lain-lain) akan sangat berpengaruh pada proses keberhasilan peserta didik itu sendiri sebagai outputnya. Permasalahan prestasi belajar yang didapat siswa memang bervariasi dari siswa yang hanya mampu mendapat nilai di bawah standar ketuntasan dan harus melakukan remidial untuk dapat memenuhi syarat kelulusan, tetapi tidak dipungkiri juga terdapat beberapa siswa yang memang berprestasi dengan baik. Dari paparan yang telah dikemukakan itu peneliti ingin melakukan kajian tentang bagaimana pengaruh motivasi yang dimiliki guru terhadap prestasi belajar peserta didik SMAN 1 Mamasa. Kab. Mamasa Prov. Sulbar.

Berdasarkan hasil observasi bahwa motivasi guru di SMA Negeri 1 Mamasa yang berpengaruh terhadap prestasi belajar terhadap peserta didik dalam pembelajarannya dengan cara yang berbeda beda. Misalnya dalam upaya yang dilakukan guru guru dalam meningkatkan prestasi belajar siswa di SMA Negeri 1 Mamasa antara lain yaitu: Pemberian penguatan yang dilakukan guru dalam bentuk kata kata pujian; Memberikan siswa waktu untuk bertanya tentang materi yang belum dipahami; Merangsang hasrat siswa dalam belajar melalui penyajian materi yang belum dipahami; dan Menggunakan metode pembelajaran yang bervariasi seperti pemakaian simulasi dan permainan berupa gambar tokoh yang menjadikan siswa lebih bersemangat dalam belajar.

Dalam kondisi yang terdapat di sekolah SMA Negeri 1 Mamasa mengenai Motivasi guru dalam melakukan pekerjaan didasari dengan sebuah tanggung jawab pekerjaan yang didalamnya mengharapkan sebuah cita atau harapan yang dinginkan guru didorongan untuk memenuhi kebutuhan-kebutuhan dasar untuk bisa bertahan hidup lebih jauh. Sedangkan terhadap prestasi belajar peserta didik di SMA Negeri 1 Mamasa cenderung Menaruh perhatian atau kedekatan guru dengan peserta didik sehingga dapat menunjukan semangat dan kegairahan dalam mengikuti pembelajaran, baik didalam kelas maupun di luar kelas. Siswa yang kurang mendapat perhatian atau kedekatan guru biasanya apatis dan tidak berpartisipasi aktif dalam belajar, menyebabkan kondisi ini dapat menyebabkan penurunan prestasi belajar.

Berangkat dari pemaparan di atas maka tujuan penelitian ini untuk mengetahui gambaran prestasi belajar peserta didik di SMA Negeri 1 Mamasa Kab. Mamasa Prov. Sul-Bar serta untuk mengetahui pengaruh motivasi guru terhadap prestasi belajar peserta didik di SMA Negeri 1 Mamasa Kab. Mamasa Prov. Sul-Bar. 


\section{KAIIAN TEORITIS}

\section{Teori Motivasi Guru}

Pengertian guru menurut Undang-undang Guru dan Dosen No.14 Tahun 2005 yaitu guru adalah pendidik profesional dengan tugas utama mendidik, mengajar, membimbing, mengarahkan, melatih, menilai, dan mengevaluasi peserta didik pada pendidikan anak usia dini jalur pendidikan formal, pendidikan dasar, dan pendidikan menengah.

Menurut Saefullah (2014:258) Dalam lembaga pendidikan, motivasi kerja para guru dapat diartikan sebagai kondisi yang berpengaruh membangkitkan, mengarahkan, dan memelihara perilaku yang berhubungan dengan lingkungan kerja di bidang pendidikan. Untuk meningkatkan motivasi kerja para guru diperlukan pengondisian dari lembaga (pimpinan) dalam bentuk pengerahan dan pemeliharaan kondisi kerja yang dapat menstimulasi kualitas kinerja. Oleh karna itu motivasi untuk berpestasi mempunyai indikator yang digunakan untuk mengukur motivasi guru antara lain: Mempunyai tanggung jawab tentang pekerjaan dan tugas lain yang terkait; Percaya pada diri sendiri berkaitan dengan cita/harapan dan keberhasilan/prestasi; Berani mengambil resiko dalam hal: pekerjaan, keuangan, dan prestasi; Umpan balik dan tindak lanjut; dan Cara baru/berinovasi berkaitan dengan: produktivitas dan efesiensi.

Motivasi sebagai proses psikologis yang terjadi pada diri seseorang dipengaruhi oleh berbagai faktor, yaitu faktor ekstern, meliputi lingkungan kerja, pimpinan, dan kepemimpinan. Selain itu faktor intern yang melekat pada diri setiap orang seperti, pembawaan, tingkat pendidikan, pengalaman masa lampau, keinginan atau harapan (Kurniadin \& Machali, 2009:333)

\section{Teori Prestasi Belajar}

Poerwanto memberikan pengertian prestasi belajar sebagai hasil yang dicapai oleh seseorang dalam usaha belajar sebagaimana yang dinyatakan dalam raport" Selanjutnya Winkel mengatakan bahwa "prestasi belajar adalah suatu bukti keberhasilan belajar atau kemampuan seseorang siswa dalam melakukan kegiatan belajar sesuai dengan bobot yang dicapainya" Sedangkan menurut Nasution prestasi belajar adalah “ kesempurnaan yang dicapai seseorang dalam berfikir, merasa dan berbuat, prestasi belajar dikatakan sempurna apabila memenuhi tiga aspek yakni: kognitif, afektif dan psikomotor, sebaliknya dikatakan prestasi kurang memuaskan jika seseorang belum mampu memenuhi target dalam ketiga kriteria tersebut (Dalyono, 2005:55)

Menurut (Slameto, 2003:54) Adapun faktor-faktor yang mempengaruhi prestasi belajar secara umum pada garis besarnya meliputi faktor intern dan faktor ekstern. Faktor intern meliputi faktor jasmaniah; faktor psikologis; dan faktor kelelahan. Faktor ekstern, dibagi menjadi 3 faktor yaitu: faktor keluarga; faktor sekolah; dan faktor masyarakat. 


\section{METODE PENELITIAN}

Penelitian ini merupakan penelitian kuantitatif, penelitian berlokasi di SMA Negeri 1 Mamasa Kab. Mamasa Prov, Sul-Bar. Populasi dalam penelitian ini adalah guru mata pelajaran di SMA Negeri 1 Mamasa Kab. Mamasa Prov.Sul-Bar, berjumlah 40 orang guru, dalam penelitian ini mengambil total sampling mengingat bahwa jumlah guru di SMA Negeri 1 Mamasa sebanyak 40 atau keseluruhan jumlah populasi (guru) dari SMA Negeri 1 Mamasa kabupaten Mamasa. Alasan mengambil total sampling karena jumlah populasi yang kurang dari 100 seluruh populasi dijadikan sampel penelitian semuanya.

Dalam mengadakan penelitian di SMA Negri 1 Mamasa Kab. Mamasa, penulis menggunakan metode pengumpulan data melalui angket, dan catatan dokumentasi.

Teknik Pengolahan data menggunakan analisis statistik deskriptif dan Analisis regresi sederhana.

\section{HASIL DAN PEMBAHASAN}

\section{Analisis Deskriptif Variabel Yang Diteliti}

Analisis deskriptif variabel dalam penelitian ini menggambarkan representasi jawaban responden terhadap kuisioner yang disebar berdasarkan perolehan skor tentang Motivasi Guru dan Prestasi belajar peserta didik.

Adapun hasil analisis deskriptif dengan mengunakan SPSS 21 disajikan sebagai berikut:

Tabel. 1 Hasil Analisis Deskriptif

\begin{tabular}{|l|r|r|}
\hline \multicolumn{2}{|c|}{ Statistics } \\
\hline Valid & Motivasi Guru & Prestasi Belajar \\
\hline Missing & 40 & 40 \\
Mean & 0 & 0 \\
Std. Deviation & 56.7250 & 79.4500 \\
Minimum & 4.51202 & 5.25723 \\
Maximum & 47.00 & 70.00 \\
Sum & 64.00 & 90.00 \\
& 2269.00 & 3178.00 \\
\hline
\end{tabular}

Hasil Olah Data SPSS

Adapun hasil distribusi frekuensi dari masing masing Variabel di uraikan sbagai berikut:

Motivasi Guru SMA Negeri 1 Mamasa Kab. Mamasa Prov. Sul-Bar 
Tanggapan responden terhadap motivasi mengajar guru dari 40 responden diperoleh total score 2269 dengan nilai maksimum 64 dan nilai minimum 47, nilai rata rata score sebesar 56.7250 serta standar deviasi sebesar 4.51202

Hasil analisi deskriptif selanjutnya dilakukan perhitungan Indeks Skor, Menurut Yusi (2009: 79) rumus perhitungan Indeks Skor (IS) untuk mengetahui besar presentase jawaban dari responden, sebagai berikut:

$$
I S=\frac{\sum \text { SkorPenelitian }}{\sum \text { SkorIdeal }} \times 100 \%
$$

Skor Ideal $=$ Nilai skala tertinggi $x$ jumlah pernyataan $x$ total sampel

Dengan membagi kriteria skor dalam 5 kriteria, sehingga jika dihubungkan dengan konsep penelitian ini maka interpretasi skor perolehan representasi skor responden terhadap pelayanan adalah:

1. $0 \%-20 \%=$ Sangat Tidak baik

2. $21 \%-40 \%=$ Tidak baik

3. $41 \%-60 \%$ = Cukup baik

4. $61 \%-80 \%=$ baiik

5. $81 \%-100 \%=$ Sangat baik

Motivasi mengajar gurudalam penelitian diukur dengan 16 butir pernyataan dengan nilai skala tertinggi adalah 4 jumlah sampel 95 sehingga score ideal:

Skor Ideal $=$ Nilai skala tertinggi $x$ jumlah pernyataan $x$ total sampel

Skor Ideal $=4 \times 16 \times 40=2560$

Skor Penelitian $=2269$

$$
\begin{aligned}
I S & =\frac{\sum \text { SkorPenelitian }}{\sum \text { SkorIdeal }} \times 100 \% \\
I S & =\frac{\mathbf{2 2 6 9}}{\mathbf{2 5 6 0}} \times 100 \% \\
I S & =88,63 \%
\end{aligned}
$$

Berdasarkan nilai indeks yang diperoleh maka IS sebesar $87,46 \%$ masuk dalamkategori motivasi guru yang sangat baik.

\section{Gambaran Prestasi Belajar Peserta Didik di SMA Negeri 1 Mamasa Kab. Mamasa Prov. Sul-Bar.}

Berdasarkan hasil analisis deskriptif dengan mengunakan spss 21 diperoleh Nilai prestasi belajar peserta didik diperoleh total score 3178 dengan nilai maksimum 90 dan nilai minimum 70 , nilai rata rata score sebesar 79,45 serta standar deviasi sebesar 5,25723

Prestasi belajar peserta didik dalam penelitian diukur dengan menggunakan nilai rata rata kelas dari 40 guru bidang studi, nilai skala tertinggi tiap bidang studi adalah $100 \%$ jumlah sampel 40 sehingga score ideal:

Skor Ideal $=$ Nilai skala tertinggi $x$ jumlah pernyataan $x$ total sampel

Skor Ideal $=100 \times 1 \times 40=4000$

Skor Penelitian $=3178$ 


$$
\begin{aligned}
I S & =\frac{\sum \text { SkorPenelitian }}{\sum \text { SkorIdeal }} \times 100 \% \\
I S & =\frac{3178}{\mathbf{4 0 0 0}} \times 100 \% \\
I S & =79,45 \%
\end{aligned}
$$

Berdasarkan nilai indeks yang diperoleh maka IS sebesar 79,45\% masuk dalamkategori prestasi belajar peserta didik yang baik.

\section{Hasil Uji Bivariat}

Untuk mengukur hubungan antara variable dependen dan independen pada penelitian ini menggunakan analisis bivariat. Adapun hasil pengukuran dengan mengunakan analisis bivariat.

\begin{tabular}{|c|c|c|c|c|c|}
\hline \multirow[t]{2}{*}{ Model } & \multicolumn{2}{|c|}{$\begin{array}{l}\text { Unstandardized } \\
\text { Coefficients }\end{array}$} & \multirow{2}{*}{$\begin{array}{c}\begin{array}{c}\text { Standardized } \\
\text { Coefficients }\end{array} \\
\text { Beta }\end{array}$} & \multirow[t]{2}{*}{$\mathrm{t}$} & \multirow[t]{2}{*}{ Sig. } \\
\hline & $B$ & Std. Error & & & \\
\hline $\begin{array}{l}\text { (Constant) } \\
\text { Motivasi } \\
\text { Guru }\end{array}$ & $\begin{array}{r}52.23 \\
.480\end{array}$ & $\begin{array}{r}9.801 \\
.172\end{array}$ & .412 & $\begin{array}{l}5.330 \\
2.786\end{array}$ & $\begin{array}{l}.000 \\
.008\end{array}$ \\
\hline
\end{tabular}

Tabel 2. Hasil Analisis Uji Bivariat

\section{Coefficients ${ }^{a}$}

Hasil Olah Data SPSS 21

Berdasarkan table 2 diperoleh persamaan regresi sebagai berikut

$$
\begin{gathered}
Y=a+b x \\
Y=52 \cdot 23+0,348 X
\end{gathered}
$$

Interpretasi persamaan regresi:

Nilai konstanta sebesar 52.23 berarti apabila motivasi mengajar konstan atau tidak di tingkatkan maka besarnya prestasi belajar peserta didik sebesar 53,961

Nilai B untuk motivasi guru sebesar 0.480 dengan tanda positif menunjukan arah hubungan yang searah artinya apabila motivasi guru di tingkatkan sebanyak satu satuanmaka akan menyebabkan prestasi belajar peserta didik meningkat sebesar $48.0 \%$

Hipotesis dalam penelitian ini adalah:

HO: Tidak terdapat pengaruh yang signifikan motivasi guru terhadap prestasi belajar peserta didik pada SMA Negeri 1 Mamasa Kabupaten Mamasa

H1: Terdapat pengaruh yang signifikan motivasi guru terhadap prestasi belajar peserta didik pada SMA Negeri 1 Mamasa Kabupaten Mamasa.

Hasil penelitian menunjukan nilai signifikasi sebesar 0,008 lebih kecil bila dibandingkan dengan $\alpha$ pada taraf signifikansi 0,05 sehingga menolak $\mathrm{HO}$ dan 
menerima $\mathrm{H} 1$ yang berarti Terdapat pengaruh yang signifikan motivasi guru terhadap prestasi belajar peserta didik pada SMA Negeri 1 Mamasa Kabupaten Mamasa.

Hasil uji determinasi pada regresi linear menjelaskan seberapa besar kemampuan semua variabel bebas (independen) dalam menjelaskan varians dari variabel terikatnya (dependen). Secara sederhana koefisiendeterminasi dihitung dengan mengkuadratkan Koefisien Korelasi (R)

Tabel 3. Hasil Uji Determinasi

\begin{tabular}{|c|c|c|c|c|}
\hline \multicolumn{5}{|c|}{ Model Summary } \\
\hline $\begin{array}{l}\text { Mode } \\
1\end{array}$ & $\mathrm{R}$ & $\begin{array}{c}\mathrm{R} \\
\text { Square }\end{array}$ & $\begin{array}{l}\text { Adjusted R } \\
\text { Square }\end{array}$ & Std. Error of the Estimate \\
\hline 1 & $.41^{\mathrm{a}}$ & .170 & .148 & 4.85343 \\
\hline
\end{tabular}

Hasil Olah Data SPSS 21

Nilai R sebesar 0,41 menunjukan besarnya pengaruh motivasi guru terhadap prestasi belajar peserta didik sebesar 41\%. Nilai R Square sebesar 0,170 menunjukan kemampuan variable independent dalam menjelaskan variable devendent sebesar 17.0 sisanya sebesar 83 , dijelaskan oleh variable lain.

\section{PEMBAHASAN}

\section{Gambaran motivasi guru di SMA Negeri 1 Mamasa Kab. Mamasa Prov. Sul-Bar.}

Hasil penelitian menunjukkan dari 40 responden diperoleh total score 2269.00 dengan nilai maksimum 64 dan nilai minimum 47, nilai rata rata score sebesar 56.7250 serta standar deviasi sebesar 4.51202 nilai indeks yang diperoleh sebesar $88,63 \%$ masuk dalamkategori motivasi guru yang sangat baik.

Menurut Nana Sudjana (2011:39) bahwa dalam proses belajar-mengajar, guru mempunyai tugas untuk memberi motivasi berupa mendorong, membimbing, dan memberikan fasilitas belajar bagi murid-murid untuk mencapai tujuan. Dalam penelitian ini terlihat Guru pada SMA Negeri 1 Mamasa Kabupaten Mamasa memiliki motivasi mengajar yang sangat baik hal ini berarti bahwa guru telah benar benar menyadari fungsinya sebagai asset pengerak dalam meningkatkan prestasi belajar peserta didik.

Besarnya motivasi guru mengajar SMA Negeri 1 Mamasa Kabupaten Mamasa mendukung teori yang dikemukakan oleh Syaiful Sagala (2009:53), bahwa guru yang memiliki motivasi mengajar yang baik, tidak hanya memberikan pembelajaran sesuai dengan yang tertulis dalam kurikulum, tetapi juga membimbing peserta didik mengembangkan karya kreatif dan inovatif, membimbing peserta didik mengembangkan bakat dan minat, serta mendorong peserta didik untuk melakukan proses belajar lanjut. Selain itu, guru memfasilitasikan peserta didik untuk mengembangkan berbagai potensi non akademik, antara lain membimbing peserta 
didik mengembangkan iman dan taqwa serta membimbing peserta didik mengembangkan keterampilan social.

Sikap Guru yang memiliki motivasi yang besar ini sangat sesuai dengan anjuran Sebagaimana firman Allah SWT dalam (Q.S Al-Mujadilah/58:11) yang artinya:

Wahai orang-orang beriman! apabila kamu dikatakan kepadamu: "Berilah kelapangan di dalam majlis-majlis", Maka lapangkanlah, niscaya Allah akan memberi kelapangan untukmu. dan apabila dikatakan: "Berdirilah kamu", Maka berdirilah, niscaya Allah akan mengangkat (derajat) orang-orang yang beriman di antaramu dan orang-orang yang diberi ilmu pengetahuan beberapa derajat, dan Allah Maha teliti apa yang kamu kerjakan.

Ayat tersebut menunjukkan bahwa Agama Islam sangat menghargai guru sehingga para guru pantas mendapatkan derajat yang tinggi. Maka dari itu atas keistimewaan yang diberikan kepada guru. Guru harus mempunyai motivasi yang baik dalam proses belajar mengajar sehingga sesuai antara tugas dan derajat yang diberikan oleh Allah SWT kepada guru.

Hasil penelitian ini sejalan dengan penelitian Siti Muti'ah (2010). Meneliti dengan judul, "Motivasi Guru dalam Proses Pembelajaran Agama Islam di Madrasah Tsanawiyah Hidayatul Ma'arifiyah Pengkalan Kerinci Kabupaten Pelalawan”. Hasil penelitiannya menyimpulkan bahwa Motivasi guru dalam proses Pembelajaran Agama Islam di MTS Hidayatul Ma'arifiyah Pangkalan Kerinci Kabupaten Pelalawan di kategorikan baik, hal ini dapat terlihat dari hasil yang diperoleh adalah sebesar $75 \%$ dan berada antara $75-100 \%$.

\section{Gambaran prestasi belajar peserta didik di SMA Negeri 1 Mamasa Kab. Mamasa Prov. Sul-Bar.}

Hasil penelitian menunjukan nilai rata rata kelas dari bidang studi binaan responden yang berjumlah40 responden diperoleh total score 3178 dengan nilai maksimum 90 dan nilai minimum 70 , nilai rata rata score sebesar 79,45 serta standar deviasi sebesar 5,25723, dengan nilai indeks prestasi belajar peserta didik sebesar 79,45\% masuk dalam kategori prestasi belajar peserta didik yang baik.

Menurut Damayanti dan Mudjiono (2002:18) Belajar merupakan suatu proses internal yang kompleks, yang terlibat dalam proses internal adalah yang meliputi unsur afektif, dalam matra afektif berkaitan dengan sikap, nilai-nilai, interes, apresiasi, dan penyesuaian perasaan sosial. Beberapa prinsip dalam belajar yaitu: Pertama, belajar berarti mencari makna. Makna diciptakan oleh siswa dari apa yang mereka lihat, dengar, rasakan dan alami. Kedua, kontruksi makna adalah proses yang terus menerus. Ketiga, belajar bukanlah kegiatan mengumpulkan fakta, tetapi merupakan pengembangan pemikiran dengan membuat pengertian yang baru. Belajar bukanlah hasil perkembangan, tetapi perkembangan itu sendiri. Keempat, hasil belajar dipengaruhi oleh pengalaman subjek belajar dengan dunia fisik dan lingkungannya. Kelima, hasil belajar seseorang tergantung pada apa yang telah 
diketahui, siswa belajar, tujuan dan motivasi yang mempengaruhi proses interaksi dengan bahan yang sedang dipelajari.

Prestasi belajar ini merupakan salah satu alat ukur tingkat keberhasilan seorang siswa di dalam kegiatan proses belajar mengajar yang diikutinya di sekolah. Dengan demikian, seorang siswa mendapat prestasi belajar minimal dalam batas rangking tertentu, sering dikatakan siswa tersebut berhasil. Slameto, (2010:2)

Hasil Penelitian ini sejalan dengan pendapat Wasty Soemanto menyebutkan, pengenalan seseorang terhadap prestasi belajarnya adalah penting, karena dengan mengetahui hasil-hasil yang sudah dicapai maka siswa akan lebih berusaha meningkatkan prestasi belajarnya. Dengan demikian peningkatan prestasi belajar dapat lebih optimal karena siswa tersebut merasa termotivasi untuk meningkatkan prestasi belajar yang telah diraih sebelumnya.

\section{Pengaruh Motivasi guru terhadap prestasi belajar peserta didik di SMA Negeri 1 Mamasa Kab. Mamasa Prov. Sul-Bar}

Hasil pengujian hipotesis menunjukkan nilai signifikasi sebesar 0,008 lebih kecil bila dibandingkan dengan $\alpha$ pada taraf signifikansi 0,05 sehingga dapat disimpulkan Terdapat pengaruh yang signifikan motivasi guru terhadap prestasi belajar peserta didik pada SMA Negeri 1 Mamasa Kabupaten Mamasa.

Hasil penelitian ini mendukung teori Djamarah Syaiful Bahri. (2002:144) bahwa Motivasi guru merupakan salah satu faktor yang menentukan prestasi belajar siswa. Karena dengan adanya motivasi dari guru maka tumbuhlah minat seorang siswa untuk terus belajar demi tercapainya cita-cita sesuai dengan apa yang diinginkannya. Motivasi jika dikombinasikan dengan proses belajar serta ditunjang oleh gaya belajar, metode, media maupun sarana dan prasarana yang lainnya yang cukup memadai tentu akan menghasilkan output yang berkualitas. Profesionalisme guru dalam mengajar dan mendidik juga menjadi faktor pendukung keberhasilan siswa.

Hasil Penelitian ini sejalan dengan penelitian H.S. Bunyamin dan Diah Faujiah (2014: 38) Pengaruh Motivasi Guru Terhadap Prestasi Belajar Siswa Mata Pelajaran IPS di SDN Rajagaluh Kidul Kec. Rajagaluh Kab. Majalengka yang mnyimpulkan bahwa motivasi guru berpengaruh terhadap prestasi belajar IPS siswa, hal ini dibuktikan dari perhitungan uji korelasi 0,679 yang artinya terdapat hubungan antara motivasi guru terhadap prestasi belajar. Dapat disimpulkan bahwa motivasi guru mempengaruhi prestasi belajar siswa sebesar 44,1\% sementara sisanya 55,9\% dipengaruhi oleh variabel lain. 


\section{PENUTUP}

Berdasarkan hasil penelitian maka dapat di simpul hal hal sebagai berikut: Gambaran motivasi guru di SMA Negeri 1 Mamasa Kab. Mamasa Prov, Sul-Bar menunjukkan nilai indeks motivasi guru diperoleh sebesar $87,46 \%$ atau masuk dalam kategori motivasi guru yang sangat baik; Gambaran prestasi belajar peserta didik di SMA Negeri 1 Mamasa Kab. Mamasa Prov. Sul-Bar menunjukkan nilai indeks prestasi belajar peserta didik sebesar $88,63 \%$ masuk dalam kategori prestasi belajar peserta didik yang baik; serta Motivasi guru berpengaruh terhadap prestasi belajar peserta didik di SMA Negeri 1 Mamasa Kab. Mamasa Prov. Sul-Bar, hal ini dibuktikan dengan nilai signifikasi sebesar 0,008 lebih kecil bila dibandingkan dengan $\alpha$ pada taraf signifikansi 0,05 . Implikasi teoritis penelitian berupa saran dalam penelitian ini berdasarkan temuan hasil penelitian yaitu diperoleh nilai Nilai R Square sebesar 0,17 menunjukan kemampuan variable independent dalam menjelaskan variable devendent sebesar $17.0 \%$ sisanya sebesar $83,0 \%$ dijelaskan oleh variable lain yang tidak diteliti dalam penelitian ini. Hal ini berarti variable motivasi guru pengaruhnya kecil terhadap prestasi belajar peserta didik. Berdasarkan hal tersebut maka dalam penelitian ini disarankan: Kepada pihak sekolah disarankan untuk melakukan usaha usaha yang dapat meningkatkan motivasi guru, pemeberian motivasi ini dapat berupa pemberian penghargaan atau reward kepada guru yang berprestasi; dan Kepada penelitian yang selanjutnya untuk menambahkan variabel variable lain yang belum terungkap dalam penelitian ini.

\section{DAFTAR PUSTAKA}

A.M., Sardiman. Interaksi Dan Proses Belajar Mengajar. (PT Raja Grafindo Persada. Jakarta. 2004)

Dalyono, M., Psikologi Pendidikan. Rineka Cipta 2005,

Dimyati dan Mudjiono, Belajar dan Pembelajaran, Jakarta: Rineka Cipta, 2002,

Kurniadin, Didin \& Imam Machali, (2009) Prinsip dan Aplikasi dalam Mengelola Sekolah dan Madrasah, Bandung: Pustaka IImu

Purwanto, Ngalim. Psikologi Pendidikan. (Bandung: PT. Remaja Rosda Karya, 2004). Saefullah, 2014. Manajemen Pendidikan Islam, CV. Pustaka Setia Bandung.

Sagala, Syaiful. Kemampuan Profesional Guru dan Tenaga Kependidikan, Bandung: Alfabeta, 2009.

Slameto. Belajar dan Faktor-Faktor Yang Mempengaruhi. Jakarta: Rineka Cipta, 2003

Soemanto, Westy. Psikologi Pendidikan. Jakarta. Rineka Cipta: 2003

Sudjana, Nana, Dasar-Dasar Proses Belajar Mengajar, Bandung: Sinar Baru Algensindo, 2011 
MOTIVASI GURU DAN PRESTASI BELAJAR PESERTA DIDIK

Team Pustaka Phoenix, Kamus Besar Bahasa Indonesia, (PT Media Pustaka Phoenix, Jakarta Selatan, 2008).

Undang-Undang Republik Indonesia Nomor 14 Tahun 2005 tentang Guru dan Dosen. 